\title{
BRANCHING AND MERGING UNDER NEW YORK'S OMNIBUS BANKING LAW
}

State-chartered banks and trust companies in New York State have been permitted to open branches within their head office city since before the turn of the century. ${ }^{1}$ The large number of bank failures in the 1930's led many to propose some expansion of the branching and merger powers in order to strengthen a system seriously weakened by the Depression. ${ }^{2}$ The New York State Legislature reacted in 1934 by enacting legislation which divided New York State into nine districts within which state banks and trust companies could branch and merge. ${ }^{3}$ State banks and trust companies, however, could not branch into a city or village in which there was already located the "home office" of another bank, trust company or national banking association."

The law pertaining to branching and merging remained unchanged despite criticism and persistent lobbying for twenty-six years by the larger commercial banking institutions of the state, particularly those located in New York City. ${ }^{5}$ Agitation for reform of what was considered by disinterested students to be an archaic banking code culminated in serious legislative consideration in 1959 of a bill essentially the same as that finally enacted in 1960 . This bill, however, although vigorously pressed by the leaders of the Republican Party which controlled both houses of the New York Legislature, was defeated by a coalition consisting of the entire Democratic minority and a group of Republicans. ${ }^{6}$

The same coalition was expected to prevent passage of the 1960 legislation, ${ }^{7}$ but a sudden shift in both houses by Democratic legislators from Brooklyn and the Bronx ${ }^{8}$ resulted in swift enactment of the so-called Omnibus Banking Bill of $1960 .^{9}$ The new Omnibus Banking Law made significant changes in the law pertaining to branching and merging of banks in the New York City area. The 1960 bill

1 New York State Banking Department, Branch Banking, Bank Mergers AND THE PUBLIC INTEREST 8 (1964).

2 Ibid.

3 Ibid.

4 Ibid.

5 Ibid.

B.Y. Times, March 14, 1960, p. 28, col. 2.

7 N.Y. Times, March 16, 1960, p. 51, col. 1.

${ }^{8}$ The Democratic shift was precipitated by the addition to the bill of a hastily conceived amendment which gave to New York City savings institutions some of the branching privileges which the commercial banks were to enjoy. N.Y. Times, March 22,1960 , p. 26, col. 4.

9 Id. at 1 , col. 2 . 
and subsequent minor amendments in 1963 and 1964 amended section 105 of the New York Banking Law to read:

1. No bank or trust company or officer, director, agent or employee thereof, shall transact any part of its usual business of banking at any place other than its principal office, except as follows:

(a) A bank or trust company may open and occupy in the city or incorporated village in which is located its principal office one or more branch offices, whether or not such city or incorporated village is located entirely within one banking district, and

(b) a bank or trust company may open and occupy a branch office or branch offices in any city or village located in the banking district in which is located its principal office, provided, however, that a bank or trust company with its principal office in a city with a population of more than one million may open and occupy one or more branch offices in any county adjoining such city if such county has a population of more than seven hundred thousand; and further, provided, however, that any bank or trust company whose principal office is located in a county with a population of more than seven hundred thousand and which county adjoins a city with a population of more than one million may open and occupy one or more branch offices in such adjoining city whether or not such city is located entirely within one banking district, provided in no event shall a branch be opened and occupied pursuant to this paragraph (b) in a city or village with a population of one million or less in which is already located the principal office of another bank, trust company or national banking association, . . . except, in the case of a conversion pursuant to the provisions of this article, branch offices occupied immediately prior thereto or except for the purpose of acquiring by merger, sale or otherwise the business and property of a bank, trust company or national banking association, whether in liquidation or doing business in the usual course. ${ }^{10}$

The 1960 legislation also amended section 600 of the New York Banking Law to read:

The following mergers are hereby authorized:

(1) One or more corporations organized under the laws of this state and subject to the provisions of article three, article seven, article eight, article eleven or article twelve of 
this chapter with another corporation subject to the provisions of the same article and located in the same banking district or in the same city, whether or not such city is located entirely within one banking district; provided, however, that one or more corporations organized under the laws of this state and subject to the provisions of article three of this chapter and whose principal office is located in a city with a population of more than one million or in a county with a population of more than seven hundred thousand, if such county adjoins such city, may merge with another corporation subject to the provisions of the same article and similarly located, and further provided that any branch acquired as a result of such merger but which is not located in such city or adjoining county may be continued to be operated for a period of five years after the date of such merger even though the occupancy of such branch would otherwise be prohibited by any other provision of this chapter. ${ }^{11}$

The enactment of this legislation bestowed on commercial banks located in New York City, the only city in New York State with a population of more than one million, the right to branch into the suburban counties of Westchester and Nassau, the only counties with a population of seven hundred thousand adjoining a city with a population of one million, subject to the principal office restriction, and to merge with commercial banking institutions in these counties. Passage also enabled the commercial banks of Nassau and Westchester Counties to branch without restriction into the five boroughs of New York City and to merge with commercial banks whose principal office was located in that city.

\section{Challenges to the Validity of the Bill}

The passions which passage of this bill aroused can be attested to by statements of various Westchester political figures. State Senator William F. Condon of Yonkers stated on the floor of the Senate: "For many years we've been aware that the powerful, always greedy big banks of New York City have had their hungry eyes on Westchester." 12 Arnold D. Roseman, of Westchester's Board of Supervisors, described the legislature's action as the "rape of Westchester." 13

The passions of most suburban public officials and bankers soon subsided, but not those of Arthur T. Roth, Chairman of Nassau County's largest bank, The Franklin National Bank of Long Island, 
and the most intransigent foe of the expansion of New York City banks into Nassau County. No doubt fearful that competition from the giant banks of New York City would retard further growth of his institution, he soon termed the law "bad legislation," "illegal legislation" and "unconstitutional legislation." 14 Mr. Roth brought suit against the Superintendent of Banks of the State of New York. Besides asserting that Governor Rockefeller was unqualified to sign the banking law because of his direct or indirect interest in various banking institutions, he contested the legality of the Omnibus Banking Law on the grounds that it unduly discriminated against Franklin National and that the bill had been enacted without adherence to certain mandatory procedural requirements. ${ }^{15}$ The basis for the undue discrimination count was the allegation that the Federal Reserve Board would not permit Franklin National to continue as a "country bank" if it entered New York City with branches. "Country banks" at the time of this litigation were those outside the so-called central reserve and reserve cities. The loss of this status would result in Franklin National's being required to keep 16 or $18.5 \%$ of its deposits as cash reserves instead of $11 \%$ as it was required to do as a "country bank." 16

State Senators Daniel G. Albert of Nassau County and William F. Condon of Westchester County testified that they had not had a complete copy of the Omnibus Banking Law before them in its final form when it was passed by the Senate on March 21, 1960. ${ }^{17}$ On the basis of this and other testimony, Justice Saypol ruled that Franklin National was entitled to a judgment declaring that the Omnibus Banking Law of 1960 was void and had not become law for two reasons: (1) when it was called up for final passage on the night of March 21 or the early morning of March 22, 1960, the bill was not on the desks of the members of the legislature in final form, in violation of article III, section 14, of the New York Constitution, and (2) the existence of the original law in the archives and in the custody of the Secretary of the State of New York was in doubt and unexplained, contrary to the provisions of sections $40,41,42$ and 44 of the Legislative Law of New York State. ${ }^{18}$

The decree invalidating the Omnibus Banking Law of 1960 was handed down on March 15, 1961. ${ }^{19}$ Republican legislators in both

14 N.Y. Times, May 6, 1960, p. 43, col. 6. 1961).

15 Franklin Nat'l Bank v. Clark, 26 Misc. 2d 724, 212 N.Y.S.2d 942 (Sup. Ct.

${ }_{16}$ N.Y. Times, Sept. 20, 1960, p. 55, col. 5 .

17 Franklin Nat'1 Bank v. Clark, 26 Misc. 2d 724, 725, 212 N.Y.S.2d 942, 945 (Sup. Ct. 1961).

18 Franklin National's numerous allegations of state and federal substantive constitutional infirmities, federal preemption of the field, impairment of contract, lack of equal protection of the laws and absence of due process were not decided because the record presented a procedural ground upon which the case could be and was decided. Id. at 727,212 N.Y.S.2d at 947.

19 N.Y. Times, March 16, 1961, p. 1, col. 2. 
houses agreed the following day to re-enact the 1960 branch banking law on March $17 . .^{20}$ Legislators cited two reasons to explain the haste with which they were acting. One was the fear of a possible run on the financial institutions already located in Nassau and Westchester Counties which were enjoined by the decree from conducting business at their new locations. ${ }^{21}$ The second was indignation over what the legislative leaders and members regarded as unwarranted judicial interference with the legislative process. ${ }^{22}$ The legislature, without consideration or discussion of the merits, re-enacted the 1960 bill with a proviso which validated action taken under the act. Governor Rockefeller signed the bill on March 17, 1961. ${ }^{23}$

\section{Institutional and Structural Changes}

The passage and re-enactment of the Omnibus Banking Law of 1960 were a response to a particular social need. The movement of many families and the commercial enterprises which followed them to the suburban areas adjacent to New York City created a demand for banking facilities and resources which most objective observers believed could not be satisfied by the financial institutions located in Nassau and Westchester Counties. The Omnibus Law was the legislative response to this problem. The objective of this Comment is not to determine whether this economic need has been satisfied by this legislation, but rather to describe and analyze the movement of New York City banks into Nassau and Westchester Counties and the manner, de novo branching or merger, in which entry was accomplished; to ascertain the impact which the entry of the city banks has had on the banking public; and to posit the legal changes and reforms necessary to facilitate further the integration of the New York metropolitan community into a single banking area without altering the basic approach taken by the Omnibus Banking Law.

\section{A. Expansion Into Suburbia Via Merger}

State Superintendent of Banks, G. Russel Clark, announced that state-chartered commercial banks would, after the Omnibus Law became effective, be allowed to use unissued stock up to $5 \%$ of total authorized capital stock for acquisition purposes. He also announced that state-chartered banks would be able to purchase directly the stock of other banks in mergers. A circuitous route such as that used by Chase Manhattan Bank to acquire the West Indies Bank and Trust Company would no longer have to be followed. ${ }^{24}$ In that transaction

23 N.Y. Times, March 18, 1961, p. 26, col. 4.

24 N.Y. Times, June 21, 1960, p. 43, col. 1. 
a securities dealer purchased Chase Manhattan shares on the open market for delivery to West Indies' shareholders in exchange for the bank assets. This innovation was certainly to the benefit of mergerminded banks, but Superintendent Clark had already made clear that he was opposed to the acquisition of big Nassau and Westchester County banks by even bigger New York banks. He had said that in view of the Omnibus Law's preamble, which specifically required healthy and nondestructive competition, he would not like to see present domination of Nassau and Westchester by large suburban banks merely replaced by domination by a few big New York City banks. ${ }^{25}$

Expansion via merger has not been a conspicuously successful way for New York City banks to gain entry into the suburbs. On April 13, 1961, the State Banking Board turned down the proposal of Bankers Trust Company of New York City to acquire the County Trust Company of White Plains, the largest commercial bank in Westchester County. The Board rejected the contention that New York City and Westchester should be considered a single banking market. ${ }^{26}$ Superintendent Clark pointed out that if the Bankers Trust-County Trust merger had been approved, and if the then pending application of First National City Bank to acquire the National Bank of Westchester were approved by the Comptroller of the Currency, 75\% of the commercial banking assets of the county would be controlled by two New York City banks. ${ }^{27}$ The Comptroller, however, denied First National City's application and said: "Large scale entry by this merger would cause an unreasonable distortion and dislocation in the present and future banking structure of Westchester County." 28 The Comptroller, James J. Saxon, said that he did not object on antitrust grounds, but on the ground that the expansion of big city banks into suburbia should be gradual rather than sudden. ${ }^{29}$ The Department of Justice and the Federal Reserve Board (which has no jurisdiction in this area over nationally-chartered banks) had objected to the merger on antitrust grounds. ${ }^{30} \mathrm{Mr}$. Saxon had contended that the merger would not have resulted in a substantial lessening of competition and that there existed no possibility of First National City's acquiring a monopoly. ${ }^{31}$

The initial attempts of two other large New York City banks to merge with suburban banks of substantial size were also unsuccessful. Chase Manhattan's application to merge with the Hempstead Bank,

25 N.Y. Times, April 27, 1960, p. 49, col. 3.

26 N.Y. Times, April 14, 1961, p. 39, col. 1.

27 N.Y. Times, April 16, 1961, §3, p. 1, col. 1.

28 N.Y. Times, Dec. 20,1961 , p. 47 , col. 1 .

29 Ibid.

30 Ibid.

31 N.Y. Times, Dec. 20, 1961, p. 47, col. 1 . 
which had fifteen offices on Long Island and $\$ 76,000,000$ in assets, although approved by the New York State Banking Department, was denied. ${ }^{32}$ Chase Manhattan at this time had 105 offices and $\$ 7,578,000,000$ in assets. Chemical Bank New York Trust Company, which also had received state approval for its merger plans, was not permitted to acquire the Long Island Trust Company, Garden City, Long Island..$^{33}$ Governor Mills of the Federal Reserve Board dissented in both decisions. He contended that Nassau County was an integral part of the New York City metropolitan area and that limiting banking services in Nassau to those in existence was a guarantee to the Franklin National Bank and the Meadow Brook National Bank of lasting protection in their already dominant financial positions. ${ }^{34}$

The clear and obvious thrust of these decisions was that the federal regulatory agencies, the Federal Reserve Board and the Comptroller of the Currency, were not going to permit the absorption of large suburban branch chains by the even larger New York City banks. If the suburban area were to become an arena for competition, the large New York City banks were going to have to resort to de novo branching or the acquisition of small suburban banks. The first indication that the federal agencies would permit the largest of the New York City banks to expand via merger with small suburban banks was the Federal Reserve Board's decision of May 27, 1963, to permit Chemical Bank New York Trust Company to acquire the Bank of Rockville Centre Trust Company, located in Nassau County. The suburban institution had but three offices and less than $\$ 40,000,000$ in assets. ${ }^{36}$ The Board stated that the entry of Chemical into the local banking market would provide the community with a broader range of banking services and also would expose the two other local banks to keener competition. ${ }^{37}$ The New York banking community immediately construed the decision as an indication that the Board would permit further acquisitions provided the acquired bank was small and lacking in growth potential. ${ }^{38}$ This construction of the Board's decision was soon proven correct, for on July 26, 1963, the Federal Reserve Board approved the Bankers Trust Company's application to acquire the First National Bank of Farmingdale. ${ }^{39}$ The Board emphasized that, as Farmingdale was a somewhat passive competitor, the merger would quicken existing competition. It noted

3248 Fed. Reserve Bulz. $544-45$ (1962).

$33 I d$. at 548 .

34 N.Y. Times, May 1, 1962, p. 49, col. 5.

3549 Fed. Reserve Bull. 785 (1963).

36 Id. at $785,787$.

37 Id. at 785-87.

38 N.Y. Times, May 29, 1963, p. 41, col. 2.

3949 Fed. Reserve Bull. 1074 (1963). 
also that Farmingdale had a serious management succession problem ${ }^{40}$ and that after the merger Farmingdale would no longer have "home office protection." 41

The Federal Reserve Board has also approved the merger of First National Bank of Mount Vernon with the Chemical Bank New York Trust Company. ${ }^{42}$ The Westchester institution had only four offices and relatively few assets. ${ }^{43}$ A major consideration in the Board's decision was that Chemical's acquisition would deprive Mount Vernon of "home office protection." 44 The substantial effect of this merger on bank competition in Mount Vernon is illustrated by the approval by Comptroller Saxon, within days of the Board's decision, of branch applications by First National City Bank of New York and the National Bank of Westchester. ${ }^{45}$ Chase Manhattan, a state-chartered bank at this time, was also soon given the right to set up a branch in Mount Vernon. ${ }^{46}$ The community of 76,000 , which prior to the Board's decision had only one commercial banking institution, now had four-certainly a significant improvement. ${ }^{47}$

The position of the present Superintendent of Banks, Frank Wille, concerning mergers corresponds to that presently held by the Federal Reserve Board, i.e., that mergers will be permitted as a means of entry into the suburban banking areas only if there is no significant increase in commercial bank concentration in the combined New YorkWestchester-Nassau area. ${ }^{48}$ His position was made clear in his decision of April 22, 1965, rejecting Chemical Bank New York Trust Company's attempt to acquire the First National Bank of Yonkers. ${ }^{49}$ His reasoning in denying Chemical's bid is very significant. $\mathrm{He}$ pointed out that although the Yonkers bank had not been aggressive, did not offer trust, custodial or investment advisory service and gave Yonkers "home office protection," its absorption by Chemical would increase the concentration of commercial bank deposits in the four leading area banks by $0.2 \%$ and the percentage of offices belonging to these banks by $1.3 \% .^{50}$ Even more important in Mr. Wille's eyes, the proposed merger would eliminate a bank that by itself or by combining with another or other medium-sized banks could over a period of time become an effective competitor. ${ }^{51}$ The obvious implication of his position is that the First National Bank of Yonkers could

40 Id. at 1075 .

11 Id. at 1076.

4250 FED. RESERVE BULL. 326 (1964).

43 Id. at 327 .

44 Id. at 328 .

45 N.Y. Times, Feb. 19, 1964, p. 51, col. 1.

46 Ibid.

47 Ibid.

48 N.Y. Times, April 23, 1965, p. 47, col. 6.

49 Ibid.

50 Ibid.

61 Ibid. 
merge with a bank other than the giant four: Chemical, Chase Manhattan, First National City and Manufacturers Hanover. Mr. Wille, in fact, noted that the establishment of additional branches in Yonkers is certainly desirable, ${ }^{52}$ a proposition about which there can be no dispute.

The regulatory authorities-the State Superintendent of Banks, the Federal Reserve Board and Comptroller Saxon-have agreed that competition and the viability of the banking structure of Westchester and Nassau Counties preclude absorption of large suburban institutions by the giant four of New York City. The merger avenue to suburbia is, therefore, presently open on an appreciable scale only to the smaller New York City banks. This is as it should be, for the degree of competition should be determined by the number of banks able to offer comparable services to a given banking market. The number of rivals, not the number of offices, should be the criterion of competition.

\section{B. Expansion Into Suburbia Via De Novo Branching}

After enactment of the Omnibus Banking Law, the consensus among financial seers was that the major expansion of New York City banks into Nassau and Westchester Counties would be effectuated through acquisition of suburban institutions. ${ }^{53}$ The major New York City banks in their initial attempts to expand into the suburbs did employ the merger-acquisition device, but, as has been shown, this approach was unsuccessful. The preference which the New York City banks initially showed for expansion via merger is readily understandable, for the "home office protection" provision of the Omnibus Banking Law locked them out of the most promising locations in both Nassau and Westchester Counties. ${ }^{54}$

The first branch office of a New York City commercial bank was opened on October 28, 1960, by the First National City Bank in Plainview, Long Island. ${ }^{55}$ First National City was to become, and still is, the most aggressive "brancher" of New York City banks, partly because it was the first bank to have its merger application denied. $^{56}$ First National City also enjoyed a unique advantage over its state-chartered competitors which enabled it to branch into communities which lost "home office protection" because of mergers. The Comptroller ${ }^{57}$ would permit a branch application to be filed while a

52 N.Y. Times, April 23, 1965, p. 47, col. 6.

53 N.Y. Times, Jan. $1,1961, \$ 3$, p. 1, col. 1 .

54 N.Y. Times, June 17,1960 , p. 43 , col. 4.

55 N.Y. Times, Oct. 27,1960 , p. 51, col. 3.

56 N.Y. Times, Dec. 20, 1961, p. 47, col. 1.

57 Comptroller Saxon is a strong proponent of expansion through branching and has been so liberal in approving branch applications that before the New York Financial Writers Association he was actually jeered by officials of state-chartered banks when he said that in no banking market in the United States is there too much competition. See N.Y. Times, June 7, 1963, p. 44, col. 4. 
merger application was pending before the Federal Reserve Board. First National City was thus able to have its applications acted upon immediately after the Board's approval, if approval of the merger was forthcoming. Using this procedure, First National City was the first bank to branch into Rockville Centre after Chemical's acquisition of the assets of the Bank of Rockville Centre Trust Company. ${ }^{58}$ First National City was also the first bank to branch into Farmingdale, Long Island, after Bankers Trust acquired the First National Bank of Farmingdale. Comptroller Saxon's approval of the application to branch in this case came before, and was conditioned on, the Board's approval of the merger. ${ }^{59}$ This advantage enjoyed by nationallychartered banks was not eliminated until February 18, 1964, when the State Superintendent of Banks announced that thereafter applications for branching rights would be accepted in advance of merger approval. ${ }^{60}$

The expansionist policies of First National City brought charges by Bruce Wood Hall, Chairman of the $\$ 100,000,000$ Hempstead Bank, Hempstead, Long Island, that the bank was engaged in the "shotgun scattering of billboard branches" with the intention of "milking and destroying established local banks." ${ }^{11}$ Complaints similar to $\mathrm{Mr}$. Hall's from other suburban bankers about what they contended had been an excessive invasion of Nassau and Westchester Counties by the multibillion dollar New York City banks led to an evaluation by the Comptroller of the Currency of the claim that the rush to the suburbs was leading to "destructive competition." ${ }^{22}$ The study, conducted by economists in the Comptroller's office, must have startled the suburban banking community. The report concluded that the increase in banks in Nassau County from 1958 through 1963-a period including the three years after passage of the Omnibus Bill-had benefited the user of banking services without causing a deterioration in the aggregate rate of return on capital of the commercial banks based on Long Island. In fact, the rate of return of these banks was above that of all United States banks in the aggregate throughout the 19601963 period and was higher in 1963 than in any of the preceding five years. ${ }^{\text {e3 }}$

First National City Bank was not the sole giant New York City bank to establish branches in Nassau and Westchester Counties. Chemical Bank New York Trust Company, although the most successful acquirer via merger, is second to First National in the number of de novo branches established. Chase Manhattan has been

58 N.Y. Times, Aug. 2,1963 , p. 36, col. 6 .

50 Ibid.

60 N.Y. Times, Feb. 19, 1964, p. 51, col. 1.

61 N.Y. Times, Sept. 4, 1963, p. 51, col. 5.

62 N.Y. Times, Sept. 22, 1963, §3, p. 1, col. 2.

63 N.Y. Times, June 15, 1964, p. 45, col. 2. 
active in this regard but not as successfully as either First National City or Chemical. The suggestion has been made that Chase's recent conversion to a national bank was induced by a comment by Comptroller Saxon that his office would look more favorably upon its branch applications than the State Banking Department. ${ }^{\text {64 }}$ If this was a factor in the decision, it certainly was not an important one. The primary reason, as was stated by Chase Manhattan's president, David Rockefeller, when he announced the bank's decision, was that the increasingly troublesome and difficult limitations and restrictions placed upon the bank's operation outside New York State by various other states would be avoided. ${ }^{65}$ The decision undoubtedly was also influenced by the state legislature's shelving of bills which would have given state-chartered banks the right to lease computer time and to issue short term unsecured promissory notes-privileges enjoyed by Chase Manhattan's foremost rival, First National City Bank.

\section{Suburban Entry Into New York City Via Merger}

The Meadow Brook National Bank, the second largest bank in Nassau County when the Omnibus Banking Law was enacted, has been the only Nassau or Westchester bank to enter New York City via the merger route. Meadow Brook on September 6, 1960, acquired both the Colonial Trust Company of New York-five offices and $\$ 85,000,000$ in assets-and the Queens National Bank with $\$ 30,000,000$ in assets. ${ }^{68}$ Sidney Friedman, the bank's chief counsel, admitted that passage of the Omnibus Law had prompted the change. "The passage of the Omnibus Law," he said, "has made us fight, and we are doing it in the best way we know how. Perhaps if we can become a billion-dollar bank, we shall be able to compete with the New York banks in terms they will understand." ${ }^{87}$

Meadow Brook's entry into New York City could, however, have been effectuated under laws existing prior to 1960 . Brooklyn and Queens are part of the second banking district which also embraces Nassau and Suffolk Counties. Therefore, Meadow Brook could have merged into Colonial Trust or Queens National before 1960 and by thus changing its head office it could have acquired the right to branch into the other three boroughs of New York (Manhattan, Bronx and Richmond); for the legislation enacted in 1934 permitted a commercial bank to branch anywhere within the city of its principal office-provided that the city's population was greater than 30,000 - even if the city was not entirely within one banking district. ${ }^{68}$

64 N.Y. Times, July 15,1965 , p. 1, col. 1.

65 Ibid.

66 N.Y. Times, Sept. 7, 1960, p. 59, col. 1.

67 Id. at 63 , col. 2.

68 N.Y. BANKING LAW § 105. 
The procedure just described theoretically enables every New York City commercial bank to enter Suffolk County. A bank with its head office in Manhattan could relocate its head office in Brooklyn or Queens. A national bank would have to have the approval of the Comptroller of the Currency to move its head office. ${ }^{69}$ A statechartered bank, however, would have to merge into a Brooklyn or Queens bank in order to change the borough of its head office, for there exists a statutory prohibition against a bank's relocation of its head office outside its home county or borough. ${ }^{70}$ There is no reported instance between 1960 and 1966 of a national or state-chartered bank using this route to Suffolk, although bills which would have granted New York City banks the right to branch into Suffolk County have been introduced in both the $1964^{71}$ and $1965^{72}$ legislative sessions.

\section{Suburban Entry Into New York City Via De Novo Branching}

The Omnibus Banking Law of 1960 enables suburban banks to branch de novo into New York City without restriction, but only Franklin National Bank of Long Island has availed itself of this privilege, and its first New York City office was not scheduled to be opened until May 18, 1964. ${ }^{\text {73 }}$ The delayed entry of Franklin National into New York City is easily explained. Entry into New York City before mid-1961 would have cost the suburban giant its "country bank" status, and the increased reserve requirement, in the opinion of its chairman, Arthur T. Roth, would have resulted in a $\$ 750,000$ per year drop in earnings. ${ }^{74}$

After mid-1961 it became apparent to Franklin's management that the bank would soon lose its "country bank" status whether or not it moved into New York City-Mr. Roth reported to the New York Times that he had been told by the Federal Reserve Board that all banks holding . $4 \%$ of the average checking account deposits in the United States would be classified as "reserve city" banks. ${ }^{75}$ The bank's failure to move immediately into New York City after learning of the impending change in its status is explained by the fact that Franklin National simply did not intend to compete with the larger and solidly entrenched commercial banks of New York City. For a long time the new entrant could expect to get only the marginal business, and Mr. Roth did not wish to interrupt Franklin National's

6973 Stat. 457 (1959), 12 U.S.C. $\$ 30$ (1964).

70 N.Y. BankING LAW $\S 113$.

71 N.Y. Times, Feb. 6, 1964, p. 37, col. 7.

72 N.Y. Times, May 11, 1965, p. 33, col. 2.

73 N.Y. Times, May 12, 1964, p. 49, col. 3.

74 N.Y. Times, Feb. 1, 1961, p. 45, col. 7.

75 N.Y. Times, April 29, 1961, p. 26, col. 2. 
steady increase in earnings per share and increase in assets. ${ }^{76}$ It was not until the aggressive expansion of the New York City banks, particularly First National City, foreclosed further expansion in Nassau County that Mr. Roth announced his plans to open twenty-five offices in New York City. ${ }^{77} \mathrm{He}$ acknowledged that earnings per share would drop and that the bank's current dividend could not be increased because of the contemplated $50 \%$ increase in offices. ${ }^{78}$

\section{IMPACT ON THE PUBLIC}

As mentioned above, ${ }^{79}$ a study conducted by the Comptroller of the Currency concluded that the entry of New York City banks into Nassau County has benefited the banking public of that area and that this has been accomplished without deterioration in the aggregate rate of return on the capital of the commercial banks based in the suburbs. ${ }^{80}$ The study was limited to Nassau County, but there were no factors considered which would indicate that different conclusions would have been reached if the study had also covered Westchester County.

A comprehensive study to determine the impact of the branchingmerging phenomenon upon the public which uses banking services was undertaken by the New York State Banking Department. ${ }^{81}$ The necessary data was obtained by questionnaires sent to all commercial banks in New York State which had made acquisitions or established branches from January 1, 1951, through December 31, 1961. Because of the litigation surrounding the enactment of the Omnibus Law, activity under it did not begin in earnest until after July, 1961. Consequently, the data acquired and analyzed in the report did not pertain to most of the mergers and branching pursuant to the Omnibus Law. The study, however, is significant in that it describes the effects on the banking public of branching and merging in New York State and thus provides a basis for discussion of the impact of the Omnibus Law.

The first and possibly the most controversial issue regarding banking relates to the meeting of local credit needs. Critics of branch banking and bank mergers often claim that branch banks are not as sympathetic to local credit needs as are unit banks, that out-of-town branches are generally regarded as deposit-collecting agencies exporting loanable funds to the head office for its use, and that, as a result, the

76 From October 21, 1961, to January 1, 1964, Franklin National's assets rose from $\$ 850,000,000$ to $\$ 1,300,000,000$. See N.Y. Times, Jan. 25, 1964, p. 27, col. 6; N.Y. Times, Oct. 21, 1961, p. 25, col. 1.

77 Ibid.

78 Ibid.

79 See text accompanying notes $62-63$ supra.

80 N.Y. Times, June 15, 1964, p. 45, col. 2.

$81 \mathrm{New}$ York State Banking Department, Branch Banking, Bank Mergers ANd THE Public INTEREst (1964). 
credit needs of the locality in which the out-of-town branch is located are not adequately met. ${ }^{82}$ The proponents of branch banking insist that branches stand ready to meet all sound loan requests, that it would be poor policy and unprofitable in the long run for a branch to be insensitive to the credit needs of the local community, that branch banking enhances the mobility of funds by shifting them to areas where loan demand is greatest and that the local branch can better serve the community's needs because of the parent bank's larger loan limit. ${ }^{83}$ The study revealed that an examination of available information on loan-deposit ratios indicated that although some of the data does lend support to the critics of branch banking, most of the findings tend to cast doubt on the validity of the charge that out-of-town branches of branch banks were less active than locally based banks in meeting local credit needs. ${ }^{84}$

A variation of the claim that branch banks do not adequately serve the credit needs of their out-of-town branch communities is that a branch bank's lending policies tend to be more impersonal than those of a unit bank since the branch manager is bound by the head office "rule book" and that granting of loans is, therefore, based less upon character than upon collateral. ${ }^{85}$ Branch banks' proponents maintain that all loans which meet the normal standards of creditworthiness will be made, regardless of whether the loan is secured, and that considerations of personal friendship or local pride should not be the determining factor in granting bank loans. ${ }^{86}$ The study concluded that on this point the available evidence, although it did not all point to the same conclusion, was consistent with the proposition that out-of-town branches of branch banks, particularly large branch banks, were less active than unit banks in making unsecured loans smaller than $\$ 25,000.87$

Proponents of unit banks often claim that out-of-town branch managers have little, if any, authority to make loans, but rather must refer credit requests to the head office, which results in excessive delay and red tape. ${ }^{88}$ The data accumulated by the drafters of the report did not support this charge that borrowers were subject to greater inconvenience at out-of-town branches of branch banks than at local unit banks. ${ }^{89}$

Service charges for both regular and special individual checking accounts were found to be higher at the big branch banks than any-

82 Id. at 8.

83 Id. at 9.

84 Ibid.

85 Id. at 11-12.

$86 \mathrm{Id}$. at 12 .

87 Id. at 84 n.64.

$88 \mathrm{Id}$. at 13.

80 Id. at 87. 
where else in the state, but the study also revealed that the arrival of a branch office led to the payment of higher interest rates on savings accounts. ${ }^{00}$

The most significant finding in the report for the user of banking services was that the large New York City banks offered the most liberal terms on auto and home purchase loans. The opening of these banks has had immediate and drastic effects on the loan policies of the suburban institutions which theretofore had been immune from competitive pressure in this area. On October 3, 1962, Franklin National lowered its personal loan rates from its previous rate of $6 \%$ at discount to $4.75 \%$ at discount. This change was made to match the rates of First National City, Chemical and Chase Manhattan, which had just established branches in Nassau County. ${ }^{91}$

The report's findings-_"lower rates on most loans, higher rates on savings accounts, more liberal repayment terms and higher loan value ratios, greater availability of services and facilities and larger loan limits for the consumer" ${ }^{22}$ - constitute a strong endorsement for the further expansion of the large New York City banks throughout the metropolitan area. There can be no doubt that branch banks can and are more likely to satisfy the heterogeneity of consumer demands than local unit banks immunized from the pressure of competition.

\section{Proposed Modifications}

The passage of the Omnibus Banking Law was a step taken by the New York State Legislature to enable the banking industry to integrate the New York metropolitan community into a single banking area. The act has benefited the banking public, but changes in the New York Banking Law and the National Banking Act are necessary to promote further the public interest. Although such legislation has been considered by the New York legislature, ${ }^{93}$ this Comment does not attempt to posit fundamental changes, such as statewide branching or merging, but rather to concentrate on the weaknesses inherent in the present statutory scheme and the federal legislation which complements it, and to posit changes that will facilitate the integration of the New York metropolitan area into a single banking unit while maintaining the basic approach taken by the original Omnibus Law.

There are two structural changes which should be made in the present branching law: elimination of the "home office" protection provision, and the expansion of the area into which New York City banks can expand to include Suffolk County and those parts of the present Third Banking District-Rockland, Ulster, Orange and

$90 \mathrm{Id}$. at $141-42$.

91 N.Y. Times, Oct. 3, 1961, p. 53, col. 2.

92 N.Y. Times, Jan. 15, 1964, p. 39, col. 3.

83 N.Y. Times, Dec. 22, 1963, § 3, p. 1, col. 6. 
Sullivan Counties-which constitute an integral part of the New York metropolitan community.

The "home office" protection provision has the effect of forcing banks wishing to expand to pay a substantial premium in order to gain entry into new areas. Aside from the unfairness of this scheme, it insulates many areas from effective competition and fosters the continued lethargy of small banks.

After passage of the Omnibus Law, New York City bankers were unanimous in announcing their intention not to pay the premium that Philadelphia institutions had paid to gain entry into suburbia. However, exorbitant premiums have been paid. ${ }^{94}$ The only beneficiaries of the "home office" protection provision are the stockholders of the small suburban unit banks, and it has been the alliance between suburban and rural politicians and small bankers which has defeated all efforts to delete this provision from the Banking Law. ${ }^{95}$

The effect on the banking public when "home office" protection is lost in a certain area is certainly beneficial, for there follows a drastic increase in the number of banking institutions in the community. Within a short time after Chemical Bank New York Trust Company acquired the First National Bank of Mount Vernon, First National City, Chase Manhattan and National Bank of Westchester had opened branch offices in Mount Vernon. ${ }^{96}$ This fact, however, must deter banks from merging, for in addition to the premium paid for the branch, they are soon confronted with numerous competitors in the community when they alone paid the premium to enter.

The argument for expansion of the area into which New York City banks can branch is that many smaller communities present the potential for a very unbalanced banking business. Some wealthy suburban communities may generate a sizable time deposit and personal checking account volume but may have virtually no business loan demand. Middle class residential areas may provide substantial demand for installment and mortgage loans but inadequate deposit volume. The branch system provides for mobility of funds and can shift excess reserves for lending through other outlets of the system. Thus, an office of some branch banks may even have a loan-to-deposit ratio of over $100 \%$.

The unit bank must maintain some reasonable relationship between its total loans and total deposits. ${ }^{97}$ There is room for a wide range of portfolio composition, but generally a bank cannot operate safely with a loan-to-deposit ratio of $95 \%$ or operate profitably with

94 N.Y. Times, June 20, 1962, p. 43, col. 1.

95 N.Y. Times, June 1, 1964, p. 1, col. 6.

98 N.Y. Times, Feb. 19, 1964, p. 51, col. 1.

97 Shull \& Horowitz, Branch Banking and the Structure of Competition, 1 NaT'L BANKING Rev. 301,337 (1964). 
a ratio of $5 \% .^{98}$ And most bankers would be unsatisfied with a loan portfolio consisting entirely of real estate or installment loans. ${ }^{99}$ The unit bank, therefore, must more or less match its supply of funds with the demand for funds in a single community, whereas the branch bank system can match supply with demand for the larger and more heterogeneous area it serves.

Suffolk County is the fastest growing county in New York State665,000 in 1960 to 900,000 by December 31, $1965^{100}$-and geographically is a part of the New York metropolitan area. Its integration into the banking area of the community has been proposed annually but to date has been rejected by the state legislature. Inclusion of this county into the area into which New York City banks can branch has the support of the present New York State Superintendent of Banks ${ }^{101}$ but not that of the state legislature, for the rural block sees the piecemeal extension of the powers of New York City banks as a direct threat to their dominant position in the legislative chambers of the state.

The present day political opposition to expansion of the area into which New York City banks may branch appears to be insurmountable. An alternative and politically more palatable manner in which to achieve such expansion would be to permit New York City banks to merge with banks in an enlarged area but not to permit them to establish de novo branches there. This method of expansion would probably arouse less political opposition, for entry would be on a more limited scale; and each entry would undoubtedly be accomplished only if a substantial premium were paid to the shareholders of the local bank absorbed.

The implementation of this proposal ${ }^{102}$ would, however, require congressional modification of section 36 (c) of the National Banking Act, which provides in part:

A national banking association may, with the approval of the Comptroller of Currency, establish and operate new branches: (1) within the limits of the city, town or village in which said association is situated, if such establishment and operation are at the time expressly authorized to State banks by the law of the State in question; and (2) at any point within the State in which said association is situated, if such establishment and operation are at the time authorized to State banks by the statute law of the State in question by language specifically granting such authority affirmatively

98 Ibid.

99 Id. at 337 n. 48 .

100 N.Y. Times, May 11, 1965, p. 33, col. 2.

101 N.Y. Times, May 3, 1965, p. 51, col. 8.

102 A similar proposal, for statewide merger powers, has been made. Ibid. 
and not merely by implication or recognition, and subject to the restrictions as to location imposed by the law of the State on State banks. ${ }^{103}$

Clarification is necessary because Comptroller Saxon has said that he would construe a statute permitting statewide merging by state banks as authority for national banks to branch statewide. ${ }^{104}$ His theory is that procedurally there would be a merger-branching distinction, but in reality it would be a distinction without substance. ${ }^{105}$ Although there appears to be a significant substantive difference, ${ }^{106} \mathrm{Mr}$. Saxon does have case support for his position. In Walker Bank \& Trust Co. v. Saxon, ${ }^{107}$ the court upheld the Comptroller's action in permitting a national bank to establish a branch de novo even though the state statute permitted branching only by taking over an existing bank. However, in Commercial Security Bank v. Saxon, ${ }^{108}$ it was held that if state banks are prohibited from opening branches except by acquiring an existing bank, a nationally-chartered bank is subject to the same restriction.

Both these cases were decided in federal district courts, and until this conflict over the interpretation of "as to location" in section 36 (c) (2) is resolved either by the Supreme Court, which could conceivably take many years, or by Congress, the New York legislature is not going to act. Significant banking legislation, therefore, is not likely to be forthcoming until Congress amends section $36(\mathrm{c})(2)$ so as to insure that nationally-chartered banks are bound to exactly the same standards as state-chartered banks when attempting to establish branch offices.

In addition to its failure to subject nationally-chartered banks to the same branching restrictions as state banks, section 36 (c) (2) also is defective in its failure to give nationally-chartered banks the right to establish branches in every case where a state bank would be permitted to do so. As presently enacted, the section lends itself to an interpretation which in some cases gives a competitive advantage to state banks merely because of the type of charter they possess. The source of the difficulty is the requirement that in order for a national bank to take advantage of a state statute authorizing branching, the authorization must be "by language specifically granting such authority affirmatively and not merely by implication or recognition." 109 This added.)

103 Rev. STAT. $\$ 5155$ (1875), as amended, 12 U.S.C. $\$ 36$ (c) (1964). (Emphasis

104 N.Y. Times, Feb. 2, 1964, § 3, p. 1, col. 2.

105 Ibid.

108 See page 234 supra.

107234 F. Supp. 74 (N.D. Utah 1964).

108236 F. Supp. 457 (D.D.C. 1964).

109 Rev. STAt. § 5155 (1875), as amended, 12 U.S.C. § 36(c) (1964). 
language should be deleted and replaced with "as it has been judicially or administratively interpreted." The need for this change is dramatized by the case of Union Savings Bank v. Saxon. ${ }^{110}$ Tinker National Bank, on March 15, 1962, applied to the Comptroller of the Currency for permission to open a branch office in an unincorporated area immediately contiguous to the incorporated village of Patchogue. Permission was granted and the branch office was opened at a location close to the originally proposed site.

The Union Savings Bank of Patchogue contended that the Comptroller had violated section 36(c) (2). ${ }^{111}$ The disagreement between the parties centered upon the meaning of the words "unincorporated village" in section 105 of the New York Banking Code. The statutory language is critical, for nowhere in section 105 or in the entire Banking Code is the phrase "unincorporated village" defined. The Comptroller interpreted the words to mean any unincorporated area that might theoretically qualify for incorporation as a village under section 2 of the New York Village Law. ${ }^{112}$ This interpretation was in accordance with the interpretation given the phrase by the New York banking authorities. ${ }^{113}$

The appellant, Union Savings Bank of Patchogue, contended that the word "village" connoted an area possessed of some attributes of community life or interest-the site of the Tinker branch was not in a shopping or business district in any way distinct from the downtown business district of the incorporated Village of Patchogue. ${ }^{114}$ The court held that section 36(c) (2) was clear, and despite the fact that the Comptroller's interpretation was in accord with section 105 as interpreted by the New York banking authorities, "a national bank may branch only where a state bank branch would be authorized "by the statute law of the state in question by language specifically granting such authority affirmatively and not merely by implication or recognition.'" 115 Interpretation of a provision by the New York Banking Department, said the court, "would not be authority for the establishment of the Tinker branch." 118

And finally, steps should be taken to narrow the broad discretion which has been granted to the state banking agencies in regulating bank mergers and branching. Presently, the determination of whether the public convenience and advantage will be promoted by the establish-

110335 F.2d 718 (D.C. Cir. 1964).

111 Union Sav. Bank v. Saxon, 335 F.2d 718, 720 (D.C. Cir. 1964).

112 Id. at 721.

113 State Bank v. Bell, 197 Misc. 97, 96 N.Y.S.2d 851 (Sup. Ct. 1949), aff'd, 277 App. Div. 924, 98 N.Y.S.2d 493 (1950) (per curiam).

114 The bank site was 400 feet east of the incorporated village, and the sole reason for the selection of this location was that the "home office" rule precluded Tinker from going into the village.

115335 F.2d at 723.

116 Ibid. 
ment of an additional branch office has been left to the sole discretion of the Superintendent and the Banking Board. The courts may not control this discretion nor does the judiciary have the power to substitute its judgment for that of the administrative officials. Only where it is manifest that the Superintendent and Banking Board have exceeded their statutory authority or where their actions have been "erroneous, arbitrary, capricious, discriminatory or palpably illegal" will the court invalidate the administrative decision. ${ }^{117}$ The present Banking Law provides only for an investigation by the Superintendent of Banks when an application for a branch is made. ${ }^{118}$ A hearing is not required, and there is no statutory requirement that the Banking Board promulgate rules and regulations setting forth the standards to be applied in ruling on applications for permission to open branch banking offices.

The state legislature ought to enact legislation providing that upon the request of interested parties, including banking institutions that will be adversely affected if the application is approved, public hearings shall be held. The Banking Board should be required to promulgate rules and regulations setting forth the criteria upon which its decisions will be based and also to state publicly the reasons why a particular application has been approved or disapproved. A formalized procedure would constitute a safeguard against venality, facilitate judicial review if venality were suspected and assure the public that the need for additional banking facilities was being determined upon a rational basis.

117 State Bank v. Bell, 197 Misc. 97, 104, 96 N.Y.S.2d 851, 857 (Sup. Ct. 1949), aff'd, 277 App. Div. 924, 98 N.Y.S.2d 493 (1950) (per curiam).

118 N.Y. BANKING LAW § 29. 